ĖESTI NSV TEADUSTE AKADEEMIA TOIMETISED. 30. KOIDË

KEEMIA. 1981, NR. 1

ИЗВЕСТИЯ АКАДЕМИИ НАУК ЭСТОНСКОИ ССР. ТОМ 30

Химия. 1981, № 1

удк $552.5: 005$

\title{
P. BECKH
}

\section{ОБ ОПРЕДЕЛЯЮЩИХ ПРИЗНАКАХ ГОРЮЧИХ СЛАНЦЕВ}

\author{
(Представил О. Эйзен)
}

К горючим сланцам иногда относят каустобиолиты только сапропелитового ряда [1] и их смешанные гумито-сапропелитовые и сапропелитогумитовые разновидности [ $\left.{ }^{2}\right]$. Если логически причислить к ним многозольные гумиты (углистые сланцы), а также липтобиолитовые и смешанные на их основе разновидности, то термин «горючие сланцы» приобретает широкий смысл [']. Под гумитами и липтобиолитами подразумеваются породы, органическое вещество (OB) которых образовалось из основной массы и устойчивых частей высших растений соответственно. Первичным материалом ОВ сапропелитов считаются цианобактерии, водоросли и другие автотрофы, которые условно могут быть названы низшими растениями.

Горючие сланцы обычно связывают с буроугольной стадией преобразования и иногда с каменноугольной [3]. Анализ процесса углефикации рассеянного ОВ сапропелитового типа указывает на то, что по ряду свойств и по основным чертам молекулярной структуры оно приближается к собственно-гумусовому веществу уже на газовой стадии $\left[{ }^{4}\right]$

Из данных рис. 1, далеко не претендующих на полноту охвата взглядов, следует, что граница между горючими сланцами и ископаемыми углями весьма расплывчата; разными авторами она устанавливается в пределах содержания $\mathrm{OB} 40-80 \%$, а между горючими сланцами и породами с рассеянным ОВ - в пределах 5$25 \%$, иногда до $40 \%$ по $\mathrm{C}_{\text {opr. }}$. Самые существенные разногласия во взглядах на горючие сланцы связаны с определением их исходного ОВ - первичных биопродуцентов и

Рис. 1. Графическое представление ряда воззрений относительно границ между горючими сланцами (ГС), рассеянным органическим веществом

(РОВ) и углями по содержанию в них ОВ.

1 ENSV TA Toimetised. K 11981
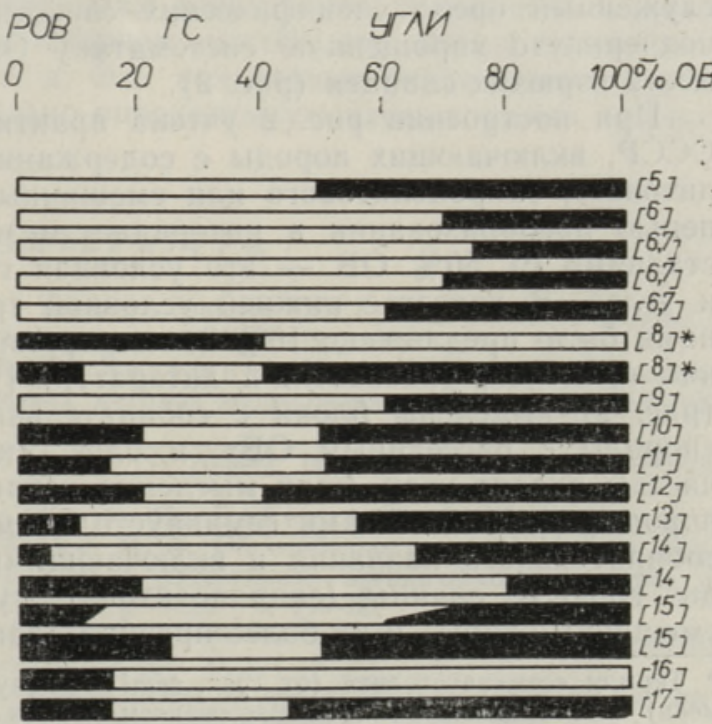

* no Copr

slik Raama ENSV TA 


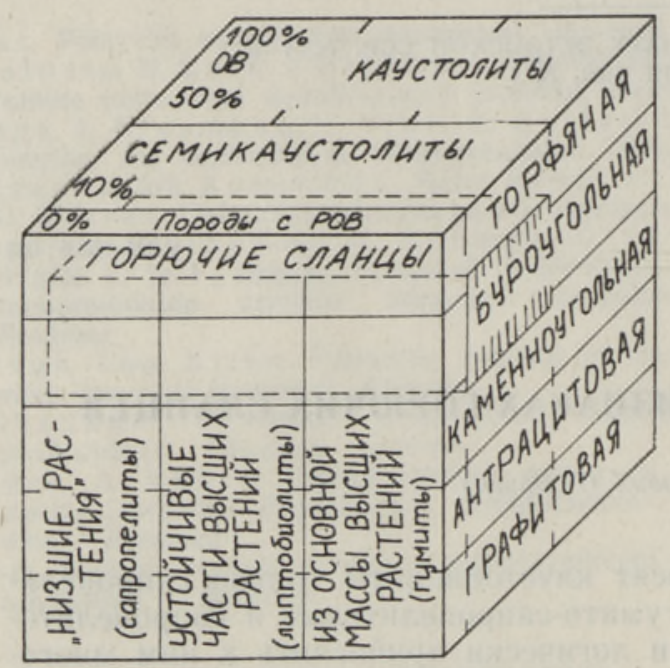

Рис. 2. Породы с РОВ, горючие сланцы и угли, разграниченные по содержанию в них ОВ, первичной биопродукции и степени преобразования ОВ. Боковая грань блока «горючие сланцы» оттенена.

границ его концентрации. Довольно часто при разграничении горючих сланцев и пород с рассеянным ОВ руководствуются не содержанием ОВ в породах, а их теплотворной способностью или выходом смолы полукоксования ['].

Уточнение понятия «горючие сланцы» имеет ключевое значение не только для химии и технологии твердых топлив, но и для химии нефти, а также при изучении нефтеобразования и оценке нефтематеринского потенциала седиментитов. Однако до сих пор этот термин относится к числу наименее определенных среди каустобиолитов.

Неопределенность термина «горючие сланцы» стала причиной появления новых терминов, например «семикаустолит» $\left[{ }^{18}\right]$ или «битумолит» [19]. Но без уточнения вкладываемого в термин содержания это не дает выхода из положения. Нередко в специальной литературе по твердым топливам невозможно вообще найти термин «горючие сланцы» $\left[{ }^{20,21}\right]$. Как правило, горючие сланцы не попадают в классификацию каустобиолитов, а если и попадают, то характеризуются как «особые» твердые горючие ископаемые [3] или как «специальные» виды твердых топлив $\left[{ }^{22}\right]$. Недостаточно разъяснена связь горючих сланцев с углями и во многих других учебных пособиях [23-25]. Противоречивость, недостаточная освещенность термина «горючие сланцы» и незаслуженный ореол специфических свойств побуди.ти нас предложить подчеркнуто упрощенную систематику ОВ пород с уточнением в ней места горючих сланцев (рис. 2).

При построении рис. 2 учтена практика подсчета запасов углей в СССР, включающих породы с содержанием ОВ гумусового, липтобиолитового, сапропелитового или смешанных типов $50 \%$ и выше со степенью преобразования в интервале между торфяной и графитовой стадиями [']. $50 \%$ ОВ - это условная граница для горючих сланцев и углей. В качестве нижней условной границы для горючих сланцев нами было предложено $10 \%$-ное содержание ОВ $\left[{ }^{26}\right]$, т. е. один из нижних пределов, указанных в литературе $[14,27]$. На верхней грани куба (рис. 2) выделены блоки с собирательными названиями пород: блок «породы с рассеянным ОВ» и блок «каустолиты», куда составной частью входят угли. Если мысленно исключить эти блоки, то остаются породы, названные нами семикаустолитами *, не имевшими до сих пор собирательного-названия и включающими сапропели, торфяные породы, горючие сланцы (сапропелитовые, гумитовые, липтобиолитовые и смешанные типы) и их более преобразованные аналоги.

* Термин «семикаустолит» (от греч. sēmi - полу, kaustós - горючий, lithos - камень) был,предложен Н. Б. Вассоевичем взамен термина жгорючие сланцы» [18], но больше он подходит в качестве собирательного, объединяющего как горючие сланцы, так и его менее или более преобразованные аналоги. 
Относительно рис. 2 нельзя не отметить еще один нюанс. Уже Г. Потонье $\left[{ }^{28}\right]$ разделял каустобиолиты в зависимости от исходного вещества и связывал их с конкретной химической структурой. С тех пор сложилось представление об алифатичности ОВ сапропелитов и ароматичности ОВ гумитов. Г. Потонье же имел в виду только малопреобразованные представители каустобиолитов. Известно, что по мере преобразования ОВ пород приобретает все более и более ароматическую структуру. Поэтому методически ничем не оправдано использование сапропелевого ОВ и алифатического ОВ как синонимичных терминов. Ароматические структуры в сапропелитах не всегда могут служить указанием на присутствие в них гумусового материала, поскольку они могли образоваться в результате преобразования первичного алифатического материала сапропелита.

Очень подробно содержание терминов «сапропелевое» и «гумусовое» ОВ рассмотрено Н. Б. Вассоевичем [29], справедливо отмечающим, что неопределенность этих терминов «существенно затрудняет использование их в строго научной литературе». Но, с другой стороны, эти термины продолжают оставаться наиболее употребительными в химии и технологии твердых топлив и нефтей. Қакой же выход из положения? Такой выход есть, и он довольно прост. Термины «сапропелевое», «гу. мусовое» и «липтобиолитовое» ОВ необходимо связывать только с исходными первичными биопродуцентами: высшими и низшими растениями, цианобактериями и т. д.

Предложенная на рис. 2 систематика пород позволяет достаточно однозначно определять любые типы ископаемых с нетрадиционных позиций. Горючий сланец определяется как порода, содержащая от 10 до $50 \%$ сингенетичного по осадкообразованию, малорастворимого в низкокипящих органических растворителях ОВ буроугольной и в некоторых случаях частично торфяной и каменноугольной стадий преобразования. Горючие сланцы, в свою очередь, разделяются на сапропелевые, липтобиолитовые, гумусовые или смешанные типы, так же как и породы с рассеянным ОВ и ископаемые угли. Горючие сланцы могут быть разбиты на классы по любым другим характеристикам, в том числе и по признакам, интересующим энергетиков, технологов и других специалистов, таким как теплотворная способность, выход смолы полукоксования, состав золы и т. д. Эти конкретные утилитарные классификации включают в себя только определенную часть горючих сланцеь.

\section{ЛИТ Е Р АТ У Р А}

1. Геология месторождений угля и горючих сланцев СССР, т. 12. Общие данные по угольным бассейнам и месторождениям СССР. М., 1978.

2. Ги н збург А. И., Л а по А. В., Л етушова И. А. Рациональный комплекс петрографических и химических методов исследования углей и горючих сланцев. Л., 1976.

3. Аронов С. Г., Нестеренко Л. Л. Химия твердых горючих ископаемых. Харьков, 1960.

4. Радченко О. А., П арп арова Г. М., Лебедев Б. А., Жукова А. В., $\Phi$ а й з уллин а Е. M., Ша к с И. А. Об особенностях углефикации сапропелевых углей, горючих сланцев й рассеянного органического вещества пород. - Тр. ВСЕГЕИ, нов. сер., 1975, т. 261, с. $21-38$.

5. С та дн и ко в Г. Л. Ископаемые угли и горючие сланцы. - Химия тв, топлива, 1932 , т. 3 , вып. $7 / 8$, с. $453-476$.

6. С тадников Г. Л. Происхождение углей и нефти. Химия превращений органических веществ в течение геологических перцодов. М.-Л, 1937.

7. Жем чужников Ю. А. Общая геология ископаемых углей. М., 1948.

8. В а ссоевич Н. Б. Основные закономерности, характеризующие органическое 
вещество современных и ископаемых осадков. - В кн.: Природа органического вещества современных и ископаемых осадков. М., 1973, с. 11-59.

9. Козлов В. П., Т окарев Л. В. Основы генетической классификации каустобиолитов. М., 1957.

10. Жемчужников Ю. А., Гинзбург А. И. Основы петрологии углей. М., 1960.

11. Геология месторождений угля и горючих сланцев СССР, т. 11. Горючне сланцы СССР. M., 1968.

12. Т а упи ц К. С. Получение жидких углеводородных продуктов из твердых топлив. - Переработка углеводородов, 1977, № 9, с. 79-89.

13. Оз еров И. М., Полозов В. Я. Основы промышленной классификации горючих сланцев. - В кн.: Разработка и использование запасов горючих сланцев. Таллин, 1970 , с. $167-171$.

14. С теф анов а Е. И. Месторождения горючих полезных ископаемых, т. 4. Горючие сланцы зарубежных стран. Итоги науки и техники. М., 1973.

15. Геологический словарь, т. 1 и 2. М., 1978.

16. Котл уков В. А. Введение. - В кн.: Формация горючих сланцев. Методы изучения и генетическая классификация. Таллин, 1973, с. 5-6.

17. Полозов В. Ф., Оз еров И. М. Промышленная классификация горючих сланцев. - Химия тв. топлива, 1974 , № 5, с. $81-84$.

18. В а ссоевич Н. Б. Литология и органическая геохимия. - В кн.: Органическое вещество современных и ископаемых осадков и методы его изучения. M., 1974 , с. $16-32$.

19. В ыче в В. Битумолиты - новый термин для обозначения «горючих сланцев». Нафтена и въглищна геология, 1977 , кн. 7 , с. $70-74$.

20. Г речишников Н. П. Методы исследования вещественного состава твердых горючих ископаемых. М., 1964.

21. К и рюков В. В. Методы исследования вещественного состава твердых горючих ископаемых. Л., 1970.

22. Р у с че в Д. Д. Химия твердого топлива. Л., 1976.

23. К р а вцов А. И., Погребнов Н. И. Месторождения горючих полезных ископаемых. М., 1975.

24. К а м н в а А. И. Химия горючих ископаемых. М., 1974.

25. Francis, W. Fuel and fuel technology, v. 1 and 2. Pergamon Press, OxfordLondon - Edinburgh - New York - Paris - Frankfurt, 1965.

26. В ески Р. Э. О границах концентрации органического вещества в горючих сланцах. - В кн.: Методы оценки нефте- и газоматеринского потенциала седиментитов. Семинар. МГУ, 25-26 декабря 1979. Тезисы докладов. М., 1979, с. 150.

27. Utilization of oil shale. Progress and prospects. Departament of Economical and Social Affairs. United Nations, New York, 1967.

28. Потонье Г. Происхождение каменного угля и других каустобиолитов. М.-Л.Грозный-Новосибирск, 1934.

29. В а с сое вич Н. Б., Г усев а А. Н., З а сл авский Е. М. К изучению рассеянного органического вещества седиментитов. Критические замечания. В кн.: Органическое вещество современных и ископаемых осадков и методы его изучения. М., 1974, с. $311-325$.

\section{Ннститут химии \\ Академии наук Эстонской ССР}

Поступила в редакцию $1 / \mathrm{IV} 1980$

\section{R. VESKI}

\section{POLEVKIVI MÄARAVATEST TUNNUSTEST}

Artiklis on pōlevkivi pōhiliste määravate tunnustena esitatud orgaanilise aine sisaldus $(10-50 \%)$ ja selle muundumise aste (enamikul juhtudel pruunsöe staadium).

\section{R. VESKI}

\section{ON THE DETERMINATION OF OIL SHALE}

The use of terms «oil shale», «rocks with dispersed organic matter» and «coal» is discussed. Oil shale is determined as a rock, the organic and mineral matter of which has been deposited simultaneously and contains $10-50 \%$ of organic matter poorly soluble in low-boiling organic solvents, the degree of transformation of which corresponds to the brown coal stage in the majority of cases. 